\title{
R. V. SHEARING: A "Five-Fingered" GUIDE TO ADMISSIBILITY?
}

\author{
James G. Pickard*
}

On 18 July 2002, the Supreme Court of Canada released its decision in $R$. v. Shearing.' In the 7-2 decision, the Supreme Court made important rulings on two issues: (1) the use of similar fact evidence, and (2) the distinction between production and admissibility relating to third-party records. While both these rulings are important, this comment will focus on an element of the latter ruling: the separation of possession from production.

In endorsing the distinction between the possession and production of third-party records, the Supreme Court adopted a results-oriented approach in which several inappropriate conclusions were drawn. Due to this lack of logical reasoning, Shearing could produce a frightening result: a defendant could avoid production proceedings by simply attaining a third-party record unlawfully or through coercion.

\section{FACTS}

The defendant Ivon Shearing was the leader of a cult called the Kabalarian Philosophy. ${ }^{2} \mathrm{He}$ preached that young women could reach higher levels of enlightenment through sexual experiences. ${ }^{3}$ As the leader of the cult, the defendant proclaimed that he was instrumental in reaching this enlightenment. ${ }^{4}$ Two sisters, KWG and SG, alleged that they were sexually abused during their childhood when they lived in the group residence with their mother. ${ }^{5} \mathrm{KWG}$ and SG were not members of the cult and lived with the defendant only because their mother was a member and a resident housekeeper. ${ }^{6}$ KWG had kept a diary for an eight-month period in 1970 when she was fourteen years old. ${ }^{7}$ This eight-month period coincided with the alleged period of abuse. $^{8}$

At the age of twenty, KWG left the house "extremely quickly" for reasons left unexplained." At that time, KWG's mother packed all of her remaining belongings into a cardboard box which was stored in the basement. ${ }^{10}$ This was done to conserve space

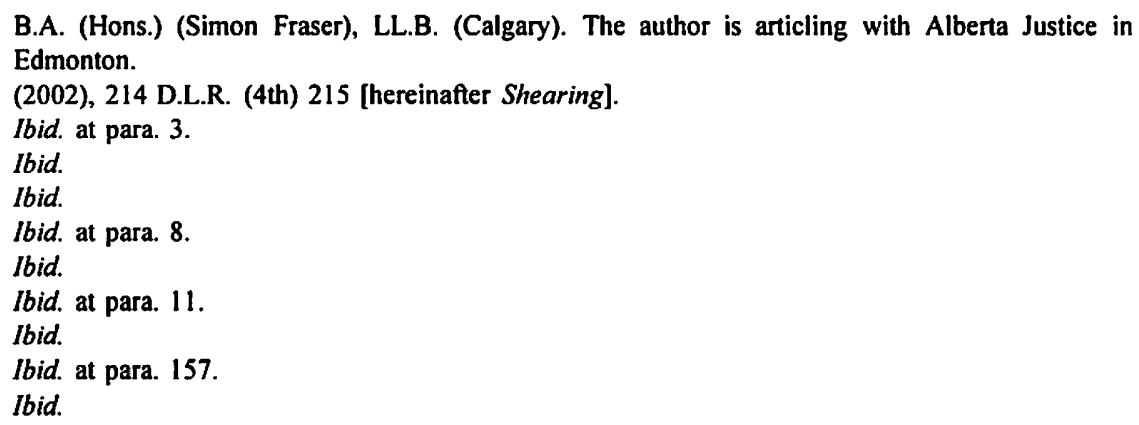


because the family shared one room." Each resident had their own box and area for storage in the basement; there was no sharing of boxes or storage areas. ${ }^{12}$

Twenty-two years later - and two years after the mother had left the house Dorothy Rollins, a long-time resident, "discovered" the diary in the storage box..$^{13}$ Rollins knew the box was not in her area of the storage room. ${ }^{14}$ Upon "discovering" the diary Rollins opened the locked diary, despite knowing it was not her own." Rollins then saw KWG's name printed on the front page. ${ }^{16}$ She decided to give the diary to the defendant. ${ }^{17}$

\section{The LOWER COURT DeCISIONS}

At trial, counsel for the defendant introduced the diary at the beginning of crossexamination and attempted to use it to contradict the testimony of KWG. ${ }^{18}$ At the ensuing voir dire, Henderson J., of the British Columbia Supreme Court, allowed limited use of the diary: the defendant could cross-examine KWG on the diary, but no reference to the absence of any written commentary on the sexual abuse was permitted. ${ }^{19}$ This limitation was justified because any such reference would have perpetuated "rape myths" and would have been based on the biased premise that sexual assaults, had they occurred, would have been recorded in the diary. ${ }^{20}$

While Henderson J. did address the defendant's use of the diary, the question of lawful possession was deemed irrelevant. Henderson J. states:

I am inclined to the view that K.W. did not abandon her property interest in the diary either. although that is less clear. Having ignored the document for $\mathbf{2 0}$ years or more, one might conclude that she had abandoned the property interest in it. I do not need to decide that issue on the present application. ${ }^{21}$

Henderson J. also held that the third-party record provisions did not apply because the sections dealt only with production and, as the diary was already in the hands of the accused, it did not need to be produced. ${ }^{22}$ The defendant was later convicted by jury of sexually abusing the two sisters and procuring sexual acts through fraud against five other complainants. ${ }^{23}$ At the Court of Appeal, Donald J.A. upheld the disclosure rulings of the trial judge. ${ }^{24}$ Donald J.A. did not address the ownership of the diary.

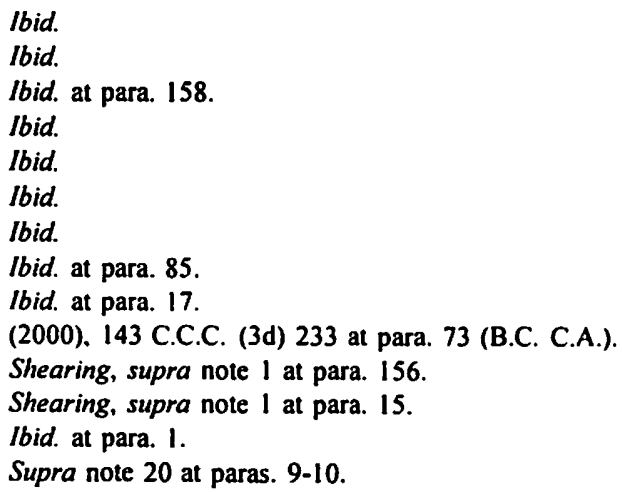




\section{The SuPREme Court Decision: The “Five-Fingered DisCounT"}

There are two critiques that can be made of the Supreme Court decision. First, the majority ignored the issue of ownership and used unsupported language in an attempt to forestall two "uncomfortable" options. Second, despite this attempt, there is now judicially endorsed incentive for a defendant's malfeasance.

\section{A. The FaILed CONSIDERATION OF OWNERSHIP}

It appears that KWG had ownership of the diary at the date in question: the diary had been given to her as a Christmas present in her early teens. ${ }^{25}$ Therefore, the current determination of ownership hinges on whether KWG abandoned the diary. Reference to both the facts and property principles indicate that no such abandonment occurred.

In discussing the concept of abandonment, Ray Andrews Brown states:

[abandonment is] "a giving up, a total desertion, and absolute relinquishment" of private goods by the former owner. It may arise when the owner with the specific intention of desertion and relinquishment casts away or leaves behind his property. ${ }^{26}$

Bruce Ziff reiterates Brown's focus on the intention of the owner:

abandonment involves the converse of possession-taking: there must be an intention to relinquish title, that is, an indifference as to the fate of a chattel, coupled with sufficient acts of divestment. ${ }^{27}$

During the voir dire, KWG stated that she had no intention of relinquishing her stored property. She believed that her belongings were being temporarily held in her mother's care. ${ }^{28}$ She also believed that the diary - and her other stored belongings - would later be returned to her. ${ }^{29}$ Furthermore, there had been no acts of divestment: the diary was locked and kept in KWG's own storage box in KWG's own storage area ${ }^{30} \mathrm{KWG}$ had not, therefore, abandoned her stored property. She maintained ownership of the diary and the possession by Shearing was unlawful.

Despite Shearing's wrongful possession, Binnie J. summarily dismissed any ownership discussion:

I do not propose to pursue any property ownership debate. The issue for present purposes is not the "ownership of the diary" (which could be the subject of a civil cause of action) but the status of

Shearing, supra note $I$ at para. 84.

R.A. Brown. The Law of Personal Property (Chicago: Callaghan, 1955) at 9.

B. Ziff, Principles of Property Law (Scarborough: Carswell, 1996) at 127.

Shearing, supra note 1 at para. 157.

lbid.

Ibid. 
information contained in the diary ... Our concern here is with the privacy interest not the property interest. ${ }^{31}$

However, this dismissal did not stop Binnie J. from forming legal conclusions:

I do not think KWG was illegally deprived of possession of the diary.... She simply left it behind in a common storage room with other possessions no longer required for day-to-day living. When her mother forwarded her possessions to her in 1995, the diary was not among them. When the diary fell into the appellant's possession 22 years after KWG left home, it was not a "wrongful" taking in any legal sense. ${ }^{32}$

Justice Binnie later reiterates his position on the legality of the possession by stating that "[the $O$ 'Connor criteria] simply does not apply to evidence already lawfully in the possession of the defence."

Why would Binnie J. refuse to ask who owned the diary? Why did he jump to a legal conclusion? Why did he decide that Shearing's possession was legal? Perhaps the answers can be found in the Supreme Court's decision to separate the concepts of possession and production.

Justice Binnie distinguished between production and possession through reference to the Preamble of Bill C-46 - later ss. 278.1 to 278.9 - and the procedural requirements established therein. The majority decision was clear in its interpretation of the interplay between possession and production: the two concepts are distinct and independent. Justice Binnie states:

He did not seek "production" under ss. 278.1 to 278.9 of the Criminal Code... The simple fact is that the defence had possession of the diary. It was not engaged in a "fishing expedition". The issue for the trial judge was the admissibility of the contents. ${ }^{34}$

Justice Binnie's intention to separate possession from production is also seen in his dismissal of an argument made by KWG and the Women's Legal Education and Action Fund (LEAF). Counsel for KWG and LEAF both argued before the court that the diary - and any copies of it - should have been returned to the complainant and the defendant ought to have sought production through ss. 278.1 to 278.9. ${ }^{35}$ Such an approach would have made the possession of the diary irrelevant; possession would not displace production. ${ }^{36}$ In dismissing this argument, Binnie J. held that such an

$3 \quad$ lbid. at paras. $89,93$.

$32 \quad$ Ibid. at para. 88 [emphasis added].

$33 \quad$ Ibid. at para. 105 [emphasis added].

34 Ibid. at paras. 22,96 .

is $\quad$ lbid. at paras. $95-97$.

3. The wording of s. 278.2(2), appears to endorse such an approach. The section states:

Section 278.1, this section and sections 278.3 to 278.91 apply where a record is in the possession or control of any person, including the prosecutor in the proceedings, unless, in the case of a record in the possession or control of the prosecutor, the complainant or witness to whom the record relates has expressly waived the application of those sections 
interpretation was "unduly contrived and does violence to the statutory language." 37 Justice Binnie continued, saying that such an interpretation

draws the alleged purpose of ss. 278.1 to 278.9 too widely (certainly much more widely than the preambular language) and presumes that the court can rewrite the text of the statute to accord with the court's own extrapolation of Parliament's purpose. This cannot be correct.... In my view it would be undesirable to twist the language of ss. 278.1 to 278.9 as suggested by LEAF. The limits of Parliament's intention, as expressed in the language it has used, should be respected. ${ }^{38}$

Due to the distinction drawn between possession and production, Binnie J.'s recognition of Shearing's wrongful possession would have led to a choice between two "uncomfortable" options. First, the majority could have maintained their emphasis on the separation between possession and production. This approach would prohibit consideration of the production sections where the defendant has possession of the records. However, such a position would have permitted Shearing to directly benefit from his wrongful possession. Alternatively, the majority could have applied the production sections despite Shearing's possession of the diary. This approach would have prevented Shearing from profiting from his own malfeasance. However, this position would also have contradicted and invalidated the possession and production distinction.

While Binnie J.'s finding of legal possession obscures the choice that would have otherwise faced the court, this holding still has dangerous consequences. By not fairly addressing the ownership issue, Binnie $J$. has concealed the potential danger of Shearing. Unfortunately, the distinction between possession and production is sure to encourage thievery and manipulation in later cases. By not fairly addressing ownership and maintaining the possession/production distinction, the Supreme Court has in fact selected the first "uncomfortable" option.

\section{B. Judicial Permission to Steal and Manipulate?}

While the failure of the Supreme Court to address the ownership of the diary casts the judgment into question, Binnie J.'s failure to address ownership has a widespread, more odious impact: it condones theft and coercion. In classifying possession and production as two distinct concepts, Binnie $\mathrm{J}$. has permitted a defendant to directly influence the role and impact of the production sections. A defendant, or an independent party intending to protect a loved one, may steal, coerce, or manipulate in order to obtain possession of a complainant's diary or other personal record. Such theft or manipulation may attract further criminal sanction; however, due to the seriousness

[emphasis added].

The possession of the record appears to be irrelevant: the production sections will still apply if the records are in the possession or control of "any person." As a result, s. 278.2(2) requires the use of ss. 278.1 to 278.9 in all cases where an unwaived third-party record is sought. Unfortunately, s. 278.2(2) was neither addressed nor explained by Binnie J. 
of sexual offence allegations, the prosecution of such "petty" crimes is unlikely to deter future malfeasance. ${ }^{39}$

Quite simply, Shearing permits a defendant to benefit from theft. The benefit is obvious: by theft, the stricter production sections can be avoided, leaving only the admissibility standards to be met. The relevant production section states:

In determining whether to order the production of the record or part of the record to the accused, the judge shall consider the salutary and deleterious effects of the determination on the accused's right to make a full answer and defence and on the right to privacy and equality of the complainant or witness, as the case may be, and any other persons to whom the record relates and, in particular, shall take the factors specified in paragraphs $278.5(2)(a)$ to $(h)$ into account. ${ }^{40}$

This production section is a codified version of the "balancing of interests" test described in the dissenting judgement of L'Heureux-Dubé J. in $R$. v. $O^{\prime}$ Connor. ${ }^{41}$ In $R$. v. Seaboyer, McLachlin J. stated that evidence is admissible until the probity of the evidence is "substantially outweigh[ed]" by the prejudice caused by its admission. ${ }^{42}$ Clearly, the $O^{\prime}$ Connor test for production is much stricter than the Seaboyer test for admission. It is the difference between these two standards that may motivate a defendant to seek possession of a record. According to Shearing, a defendant who possesses a record will not have to pass the $O^{\prime}$ Connor standard but must only meet the lesser admissibility standard of Seaboyer in order to use the document at trial..$^{43}$

Even more troubling is the potential benefit of manipulation and coercion. Sexual assaults involve an abuse of power and control. ${ }^{44}$ Victims of sexual assault often know their perpetrator. ${ }^{45}$ As a result of this power imbalance, it may be quite easy for an accused to exert influence over a complainant in an attempt to gain possession of any

Perhaps the use of an obstruction of justice charge could provide an effective deterrent. Section 139(2) of the Criminal Code states:

Everyone who wilfully attempts in any manner ... to obstruct, pervert, or defeat the course of justice is guilty of an indictable offence and liable to imprisonment for a term not exceeding ten years.

The indictable classification and the ten-year maximum sentence provide a potentially more effective alternative to the lesser charges of theft, fraudulent concealment, mischief, criminal harassment, and uttering threats. Section 139(3) outlines how "obstruct, pervert, or defeat" can be defined; however, this description is merely illustrative, not exhaustive, and thus allows for the broad application of the charge. Criminal Code, R.S.C. 1985, c. C-46, s. 278.7(2) [emphasis added].

[1995] 4 S.C.R. 411 at paras. 129, 150 [hereinafter $O^{\prime}$ Connor].

[1991] 2 S.C.R. 577 at 611 [hereinafter Seaboyer].

This position reintroduces the reasoning underlying the pre-Charter decision of $R$. v. Wray, [1971] S.C.R. 272. In Wray, the Supreme Court held that evidence found to be admissible would not be excluded even if obtained by improper means. Admissibility was the determinative step. While the advent of the Charter has dismissed this reasoning in addressing the actions of a government actor, the Supreme Court in Shearing has reintroduced the admissibility standard as a potentially determinative factor in the use of third-party records. 
records. In distinguishing between possession and production, Binnie J. may have unwittingly opened the door to the further victimization of sexual assault complainants.

\section{Conclusion}

The faulty reasoning and shortsighted conclusions of the Supreme Court are worthy of concern. A defendant may now wrongfully obtain a third-party record and avoid the strict production requirements. Parliament may "correct" the Supreme Court's error through the use of "dialogue" endorsed in R. v. Mills. ${ }^{46}$ In the meantime, victims of sexual assault will have to wait for adequate legal protection.

4. [1999] 3 S.C.R. 556. See generally J. Cameron, "Dialogue and Hierarchy in Charter Interpretation: A Comment on R. v. Mills" (2000) 38 Alta. L. Rev. 1051; P.W. Hogg \& A.A. Bushell "The Charter Dialogue between Courts and Legislatures (or Perhaps the Charter of Rights Isn't Such a Bad Thing After All)" (1997) 35 Osgoode Hall L.J. 75. 